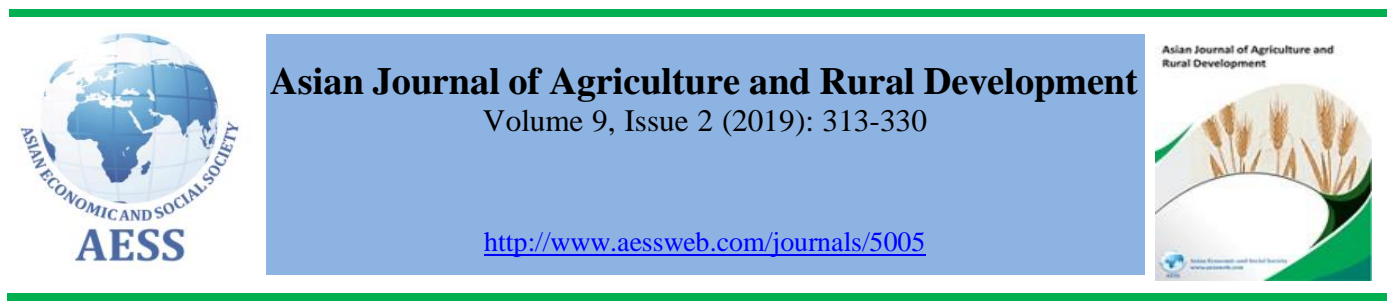

\title{
ACCELERATING AGRICULTURAL PRODUCTIVITY AND MARKETING FOR RURAL TRANSFORMATION IN NIGERIA
}

Evelyn Nwamaka Ogbeide-Osaretin ${ }^{\text {a }}$,

Ben Ozougwu ${ }^{\text {, }}$

Oseremen Ebhote

\section{ARTICLE HISTORY:}

Received: $13-$ Sep-2019

Accepted: 16-Dec-2019

Online Available: $31-\mathrm{Dec}-$ 2019

\section{Keywords: \\ Agriculture, \\ Gender, \\ Rural, \\ Transformation, \\ Total factor productivity}

a Department of Economics, Faculty of Arts, Management and Social Sciences, Edo University Iyamho, Edo State, Nigeria

${ }^{\mathrm{b}}$ Department of Economics, University of Nigeria, Nsukka, Nigeria

${ }^{c}$ Department of Business Administration, Faculty of Arts, Management and Social Sciences, Edo University Iyamho, Edo State, Nigeria

\.

\section{Contribution/ Originality}

This study contributes to the present literature as it relates to agricultural productivity and marketing as a tool for economic development by specifically analyzing the important role of gender towards enhancing the development of agricultural sector and economic development at large. It took a step away from the previous study by employing a total factor productivity measure of productivity.

DOI: 10.18488/journal.1005/2019.9.2/1005.2.313.330

ISSN (P): 2304-1455/ISSN (E):2224-4433

How to cite: Evelyn Nwamaka Ogbeide-Osaretin, Ben Ozougwu and Oseremen Ebhote (2019). Accelerating agricultural productivity and marketing for rural transformation in Nigeria. Asian Journal of Agriculture and Rural Development, 9(2), 313-330.

(C) 2019 Asian Economic and Social Society. All rights reserved. 


\section{INTRODUCTION}

Most developing countries highly rely on the rural areas for their survival yet, developmental policies (international and domestic) are usually urban biased making the rural part of often suffer lack of productive resources hence, high rural poverty. Agriculture is common and the main income source in the rural area, forming the total of about $69 \%$ of rural household's income and employing about $80 \%$ of rural working force (Barrett et al., 2017). Agriculture plays essential roles in export earnings and employment in Sub-Saharan Africa (SSA) countries. Findings showed that about seven million people will be brought out from poverty with about $10 \%$ increase in small-scale agricultural productivity in SSA as against other sectors. It accounts for about $32 \%$ of the GDP and absorbs about $65 \%$ of the labour in SSA (IAASTD, 2009). Agriculture is the bedrock for industrialization and developmental takes off (Johnston and Mellor, 1961).

Regardless of the importance of agriculture in Sub-Saharan African countries, adequate actions have not been taken on the sector hence, low productivity and welfare of the people. Irrespective of the global fall in poverty from $44 \%$ in 1982 to $10 \%$ in 2016 , about 390.3 million poor were still poor in SSA countries as at 2013 and about $82 \%$ of the poor population are in the rural areas (Beegle et al., 2016; World Bank, 2017a; World Bank, 2017b). In 2010, about 19kg per hectare of arable land of fertilizer was used in SSA, but in Asia and Pacific Region, an average of $64 \mathrm{~kg}$ per hectare of fertilizer were used. Also, while about 1.3 tractors per 1000 hectare of arable land were used in 2012 in SSA, 14.9 was used in Asia and Pacific Region (FAO, 2012); New Partnership for African Development (NEPAD, 2013). Sectorial total expenditure declined from 4.5\% in 2001 to 2.5\% in 2012 (Cadoni and Angelucci, 2013 in Mbabazi et al., 2015).

In Nigeria, agricultural sector is an important sector contributing to the growth of the country. National Bureau of Statistics (NBS, 2018) noted that agriculture dominated the labour market accounting for $48.19 \%$ of employment in 2017. Before 1970, agriculture contributed about $70 \%$ of GDP, employed about $70 \%$ of the population and to contributed to about $90 \%$ of the foreign earning and Federal government income (CBN, 2017). However, agricultural sector's contribution in total Real Gross Domestic Product (RGDP) has continued to decrease from about $30 \%$ percent in 1980 s to $6.2 \%$ in 2011 . However it increased slightly to $25 \%$ in 2016 (CBN, 2017). Food productivity in Nigeria in 2016 was as low as 124.6 making the country to rank 81 out of 190 countries assessed while the country has an arable land of $37.4 \%$ ranking 14 countries with the highest size of arable land. (TheGlobaleconomy.com, 2019). In 2014, tractors per 100sq. km of arable land was as low as 4.76 (World Bank, 2017a).

Federal Government has made efforts to enhance the sector's productivity (the Nigerian Agricultural Co-operative and Rural Development Bank of 1972, the Agricultural Credit Guarantee Scheme Fund (ACGSF) in 1977, National Accelerated Food Production Programme (NAFPP), and FADAMA programme, among others) yet productivity is low. Financial allocation to the sector that is a main income source for rural dwellers, a core driver of growth and poverty reduction in the country is very low and can be contributory to the sector's low productivity. For instance, average federal government budget for the sector between 2001 and 2005 was only 1.7\% of total government expenditure. In 2008, recurrent expenditure in the agricultural sector was only $3 \%$ falling rapidly to $0.69 \%$ in 2017 . Commercial bank loan to the sector was $1.4 \%$ in 2008 but increased marginally to $3.2 \%$ in 2017 yet, not encouraging given its importance (CBN, 2017). As a share of AGGDP, the investment in agricultural research fell from $0.39 \%$ in 2008 to $0.22 \%$ in 2014 (ASTI, 2018).

A wealth of literature relating to agricultural productivity exists on the global, regional studies, cross-country studies and country-wise studies (Africa countries and Nigeria inclusive) (Coelli and Rao, 2003; Akpan et al., 2011; Eboh et al., 2012; Adepoju and Salman, 2013; Nwangi and Kariuki, 
2015; Mensah et al., 2017). However, large number of these studies failed to consider the whole sector's productivity and looked at only one agricultural product (Akpan et al., 2011; Adepoju and Salman, 2013). Others (Chukwu, 2014) analyzed partial productivity, using estimation methods where the quality of the data was not verified. The study is carried out by Eboh et al. (2012) needs an update of the data given the recent policies in the Nigerian agricultural sector and the globe at large.

In addition, previous studies such as Olagunju (2010), Akpan et al. (2011) and Bustos et al. (2016) have not considered the role of gender in Nigeria agricultural sector's productivity as recommended by inclusive growth agenda (Kanu et al., 2014). This is because women engage more in agricultural activities than other economic activities. For instance, in 2017, 36.24\% of female workers are engaged in agricultural activities (NBS, 2018). Food and Agriculture Organization (FAO, 2012) noted that agricultural output of developing countries will increase by $3 \%$ if women are given the same amount of access to resources as gave to male. In Nigeria, women's contribution to the agricultural sector increased from 33\% in 1985 to $42 \%$ in 2016 (UNCTD, 2016). Hence, it became imperative to carry out an in-depth study to underscore the role of gender as a pre-requisite for rural transformation with particular attention on its contribution to agricultural productivity. This research is expected to provide any evidence on key policy insights for Nigeria's rural transformation through enhancing agricultural productivity.

The above background accentuates our research significance that strives to offer knowledge in three important ways: First, the study investigates into the determining factors for enhancing agricultural productivity in Nigeria using total factor productivity paradigm. Second, it investigates the gender implication towards enhancing agricultural productivity in Nigeria to achieve the goal of inclusive growth and to determine the need for gender specific policy towards Nigeria rural transformation. Third, the intensity of rainfall was introduced in the derivation of total productivity which has been neglected in previous studies. Following this introduction, section 2 provides conceptual issues and empirical literature; section 3 is the methodology section; presentation and discussion of results is on section 4 , while section 5 is a key policy priority and conclusion.

\section{LITERATURE REVIEW}

\subsection{Conceptual literature}

Agriculture is the practice of cultivating the soil and rearing of livestock to produce plants and animals, the supply of input, as well as marketing agricultural products useful to human existence (Asoegwu and Asoegwu, 2007).

Agricultural productivity according to Grosskopf (1993), is an amount of the increase in output given improvement in the factor input. It measures performance, guilds the sector's efficiency and synonymous with efficiency or technical progress. It an important causes of aggregate output growth. Hayami and Ruttan (1985) noted that agricultural productivity can be enhanced either through the increase of input or the advanced method of production. Productivity is usually measured by dividing an index of output by input(s). This can be partial factor productivity (PFP) or total factor productivity (TFP). PFP measures productivity as the ratio of output to a single input (Diewert and Nakamura, 2005 cited in Ibok et al., 2014).

$$
P F P=Y / X i
$$

Where $Y$ is total output and $X$ is input $i$ (Odhiambo and Nyangito, 2003). This is the measure often used, and labour is easily used. Hence, productivity is proxies as output per worker or output per area of land planted. This measure ignored the relevance of other input that contributes to the output change. A more accepted and generalized gauge of agricultural productivity is TFP. This is 
the ratio of total output quantity to total input quantity (Ibok et al., 2014). This is justified on the bases that a holistic and unbiased measure of productivity can only be achieved by recognizing all necessary factor inputs.

Defining rural transformation requires knowledge of structural transformation because rural transformation is built-in structural transformation. Structural transformation is the gradual change in the comparative sectorial contribution to GDP while rural transformation is the gradual improvement in the welfare and standard of living of rural dwellers through promoting investment in rural health status, educational, technological knowledge, infrastructure and diversified livelihoods (Dabla-Norris et al., 2013).

Rural transformation is concentrated in enhancing agricultural productivity, diversifying production patterns and livelihoods in the sector and it is essential to drive and is driven by structural transformation. As presented by IFAD (2016), the following among others is a number of the rural transformation agenda:

- Poverty and inequalities reduction

- Ensuring food security and accelerating agricultural development

- Creation of better jobs and economic self-sufficiency in the rural areas

- Rouse the growth of rural towns and transitional cities

- Managing convoluted and tactful issues of rural-urban migration.

- General opportunity to use essential public services such as education, health, housing, fresh water, electricity, transport and communications

- Providing widespread access to efficient and sustainable financial services and capital

- Promoting innovation, research and development with emphasis on the needs of rural people, producers and firms.

Marketing encompasses all business functions including production and in its widest sense, it also looks at the decision that pertains to production. One can say that in farming such resolution as the variation of crops to cultivate or the variety of the animal to rear is marketing decisions. Therefore, the main significance of an integrated marketing system is to add form, place, time and utility to products (Benjamin and Victoria, 2012). According to Onyeabor (2009), agricultural produce marketing portrays an image involving demands and motivation of sellers to deliver food substances to the final consumers at a reasonable profit margin. Agricultural marketing in Nigeria over the years have suffered a lot of setbacks according to Eze et al. (2010) who acknowledged produce corrosion, insufficient processing equipment, poor marketing facilities, high costs of shops, insufficient packaging information etc. as some of the difficulties of agricultural marketing in Nigeria. Rural transformation through enhancing agricultural productivity encompasses, good marketing strategies and facilities. Access to market have been one of the factors hindering agricultural productivity in Nigeria.

\subsection{Theoretical literature}

Theories tend to generalize the necessity for agricultural growth for the growth and development of any economy. In the neoclassical growth literature showing the inter-temporary changes in the development process, no economy can withstand the fixed supply of natural resources without agricultural productivity. Hence they cannot achieve a sustained economic growth. According to the Classical economist, agriculture is to be held in high esteem as its role of food supply is without substitute towards stimulating economic growth. A stagnated agrarian sector will result in large Engel coefficients for households Alliance for a Green Revolution in Africa (AGRA, 2017).

In drawing inference from these theories, Hayami (2001) noted that successful industrialization requires increased food production to avoid the "Ricardian trap" (driving the economy into a 
stationary state given the increased labour cost which is a short flow of labour from agriculture to the other sectors). Hence, increasing agricultural sector's productivity is important. Hazell and Roell (1983) in AGRA (2017) opined that the consumption linkage as a result of increased rural incomes is agriculture's most important linkage in the development process.

\subsection{Empirical literature}

Current interest on the significance of agriculture is renewed with the finding that it has the panacea for poverty reduction. The study of Johnston and Mellor (1961) was the first to show that agriculture has an important function in the development process. Linking consumption and production, they concluded that in a closed economy, growth in agricultural productivity will lead to high rural incomes, lower food prices, increased rural savings for the mobilization of capital for industries and expansion of the domestic market. Findings showed that agricultural productivity growth resulted in lower nominal wages in the manufacturing sector and more competitive agriculture and non-agricultural export through price reduction.

A global analysis of technological change and deforestation was carried out by Brady and Sohngen (2008) using cross-sectional studies of thirty countries Nigeria inclusive from 1969 to 2001. Result showed a positive effect of land on productivity. Using statistics and total factor productivity model, Adepoju and Salman (2013) investigated on the access and effect of infrastructure on agricultural productivity in Surulere and Ife, East Local Government areas of Oyo and Osun States. Farm size, extension visit and labour positively and significantly affected productivity while female labour contribution was higher than their male counterpart.

Akpan et al. (2011) analysed the determinant of productivity in a sample of 240 vegetable farmers in Akwa Ibom State. The Cobb-Douglas production function in an Ordinary Least Square estimation was used and the result revealed that farm size, age, household size, farmer's income, accessibility of water and credit are major determinants of TFP while Muzari et al. (2012) reviewed the impacts on agriculture productivity of smallholders' adopting technology in the SubSaharan Africa. Findings showed that holdings, income, labour and innovativeness by smallholder farmers among others are factors affecting technology adoption. This is in line with the study of Nwangi and Kariuki (2015) on the potential factors influencing developing countries adoption of agricultural technology. They identified technological, economic, institutional factors and human factors as the major cause of low technology adoption in agriculture in developing countries.

Iheke and Nwaru (2013), examined innovation use, farm productivity and state of poverty of rural small farm households in South-Eastern Nigeria. Using descriptive statistical tools they corroborated that the most adopted innovations/technologies were use of inorganic fertilizer, improved seed, the crop remains recycling, crop rotation and use of animal waste. Factors found influencing the adoption of innovations/technologies were gender, age, years of formal education attainment among others.

Analyzing the relevance for credit availability for productivity, Olagunju (2010) assessed the influence of credit on poultry productivity in Southwest Nigeria. Adopting a descriptive statistics, Logit and multiple regression model, it was discovered that credit acquisition by the farmers, source and amount had a significant impact on poultry productivity. This study was in agreement with Kiplimo et al. (2014) who investigated on the contributing factor of access to financial services by smallholder farmers in Kenya. Employing logistic regression, the marginal effects of education level, occupation and access to extension services were statistically significant with access to credit financial service. Household earnings and the distance to the credit source had negative significant effects on access to credit financial services. 
Bustos et al. (2016) examined the relevance of agricultural productivity in the structural transformation of Brazil and reached a verdict that a labour biased technical change will cause agricultural productivity to result in a fall in industrial employment. Chukwu (2014) looked at crop-sector agricultural productivity in Nigeria on time series data from 1970 to 2013. Employing a multiple regression and Analysis of Variance (ANOVA), agriculture was discovered to be labour intensive, effective and productive. Capital stock was gender sensitive against the female. Poor health status and lack of infrastructures in the rural areas of impaired agricultural productivity.

Alilu and Ichoku (2015) using the Malmquist Index and Tobit model analyzed the total factor productivity dynamics of thirty Sub-Saharan African countries from 1999 to 2011. Result showed a small amount of TFP growth in technical progress with about $47 \%$ and $20 \%$ having a positive trend of technical efficiency and catch-up effect respectively.

\subsection{Contribution to knowledge and gap in literature}

The demand to transform the rural sector has led to several studies on the agricultural sector particularly on the productivity and marketing of the sector given that the agricultural sector is prominent in the rural sector. An examination of previous studies showed that different measures of productivity and models have been used. General consensus tends to support improved technological advancement and credit to enhance agricultural productivity in developing countries. However, greater part of these studies concentrated on sub-sector analysis and a specific function of gender policies in enhancing full agricultural sector's productivity has been neglected. This study intends to fill this lacuna by adopting a total factor productivity measure and carrying out an analysis of the impact of gender on total productivity for effective policy framework towards transforming the rural areas.

\section{THEORETICAL FRAMEWORK AND METHODOLOGY}

\subsection{Theoretical framework}

This study adopts both the classical and neo-classical theories that underscore that agricultural productivity is the foundation for any form of transformation. A stagnated agricultural sector will have ripple-effect on all other sectors. Food supply which is based on the agricultural sector and rural area is a necessary condition for any well-being and having a good well-being is a step towards transformation. This study adopts the TFP using the Solow residual approach to account for the productivity of other factor inputs. Recognizing that productivity has also been measured in some other ways like the Malmquist productivity index adopted by Coelli and Rao (2003); Alilu and Ichoku (2015), the Malmquist index approach has been established to be in-appropriate. This is based on its submission of fundamental technology that naturally devalues productivity (Nin et al., 2003) although, it has the advantage of decomposing productivity into pure technical efficiency and change technological progress. OECD (2001) noted that it suffers from theoretical and empirical drawbacks.

\subsection{Estimation framework}

Literature provides three ways by which productivity can be estimated: The first two are the growth accounting/index numbers and the non-parametric approach. These include the Malmquist Index. They are criticized on the ground of failing to show the link between capital formation and output growth as well as their inability to point out the sources of growth (Zepeda, 2001). The third way of estimating productivity is the econometric approach. This approach accommodates the weakness of the other two, using the Solow type growth model and providing for a robust result from the estimation. Though criticized for data quality requirement, the econometric approach is most employed for study purpose. 


\subsection{The model}

For the purpose of analysis, we adopt a model that follows the Hicks-neutral Cobb-Douglas-type model.

$$
Y=A f\left(K^{a}, L^{b}\right)
$$

Where $Y$ represents output, $A, K$ and $L$ represents technology and innovation, capital and labour respectively. If we suppose our core variables change through time, we indicate this by including the time subscript " $t$ " to model (2), and the model becomes:

$$
Y_{t}=A_{t} f\left(K_{t}^{a}, L_{t}^{b}\right)
$$

For the intent of this study, we modify the production function in (3) above to include such inputs as agricultural land $(L a)$ and the degree of rainfall $(R)$ because agricultural production depends largely on the amount of rainfall in a country.

$$
Y_{t}=A_{t} f\left(K_{t}^{a}, L_{t}^{b}, L a_{t}^{\gamma}, R_{t}^{\pi}\right)
$$

To accommodate the econometric approach, we do a logarithmic transformation on (4) above.

$$
\log Y_{t}=\log \left(A_{t}\right)+\operatorname{aLog}\left(K_{t}\right)+b \log \left(L_{t}\right)+\gamma \log (\operatorname{La})+\pi \log (R)
$$

Where: $Y$ is Agricultural real GDP

$L a$ is agriculture land \% of land area.

$K t$ is capital agricultural machinery (proxy by tractors per $100 \mathrm{sq} . \mathrm{km}$ of arable land)

$L t$ is agricultural labour as \% of labour force

$R$ is average annual rainfall. A, is Solow's residual, accounting for current level of technology which is called total factor productivity.

Output increases not only because of capital and labor expansion, but also with increases in total factor productivity. 1 percent increase in total factor productivity with other inputs constant, output increases by 1 percent (Mankiw, 2002).

The Total Factor Productivity $\log \left(A_{t}\right)$, is not a constant rather it mirrors other factors working together to increase the productivity of capital and labour. It is a type of error term or residual.

Therefore:

$$
\log A_{t}=\operatorname{LogTFP} P_{t}=\hat{\mu}_{t}
$$

Substituting (6) into (5) and introducing the intercept term will lead to (7) below

$$
\log Y_{t}=\delta+a \log \left(K_{t}\right)+b \log \left(L_{t}\right)+\gamma \log (\operatorname{La})+\pi \log (R)+\mu_{t}
$$

But total factor productivity is a function of certain covariates. Following Miles and Scott (2005), TFP is a degree of efficiency upon which productive inputs are put together to produce output. The version of TFP developed by Miles and Scott recognizes the basis of TFP to include the educational level and skills of the work force, technology, institutions and government policies, amongst many other factors. So the equation for the TFP could be expressed as:

$$
T F P=f(X)
$$

Where $X$ stands for certain covariates as education measured by gross enrolment rates at the different levels of education, public expenditure in Agriculture; government recurrent expenditure 
in the sector; nominal exchange rate to account for the impact of international prices on imported farm inputs and exported farm products; agricultural loans, to account for access to finance; gender influences captured by $\%$ of female in agricultural labour force and health status measured by life expectancy rate.

Equation (8) is specifically stated as:

$$
T F P=f(\text { grospri, grossec, groster, Rexpen, Exr, Aloan, Falab, Lex })
$$

The log transformation of the above model of the variables that are not in rate is stated as

TFP $=\alpha 0+\alpha 1$ Grospri $+\alpha 2$ Grossec $+\alpha 3$ Groster $+\alpha 4 \log ($ Rexpen $)+\alpha 5$ Exr + $\alpha 6 \log ($ Aloan $)+\alpha 7$ Falab $+\alpha 8$ Lex + ei $)$

Where

TFP $=$ total factor productivity,

Grospri = primary Gross enrollment rate,

Grossec $=$ secondary gross enrollment rate,

Groster $=$ tertiary gross enrollment rate,

Rexpen $=$ government recurrent expenditure,

Exr $=$ exchange rate,

Aloan $=$ agricultural loan,

Falab $=\%$ of female in the agricultural labour force,

Lex $=$ life expectancy rate and

$e i=$ error term. Our focus will be on model (7) and (10).

\subsection{Method of estimation}

The Autoregressive Distributed Lag method of estimation was used for the estimation of the above equation given its ability to establish a baseline estimate of the relationships between the dependent variable and independent variables where the variables are of different order of integration.

\subsection{Estimation techniques}

To avoid a spurious result from using non-stationary data set, some pre-regression tests were carried out. First, the time series properties of the data were considered using the Augmented Dickey Fuller (ADF) test. The order of integration was determined for un-stationary variables. Correlation test was also carried out to determine the existence of multi-collinearity amid the variables. Diagnostic tests were further carried out.

\subsection{Data}

Secondary data was used obtained mainly from the CBN Statistical Bulletins (2017) and World Bank (WDI) (2017) and span the period from 1981 to 2016. The choice of the variables used for the study was majorly based on the availability of the data. Hence, the study was limited for data needed for some important variables such as labour force participation rate among others. E-views 9 econometric package was used.

\section{EMPIRICAL FINDINGS}

\subsection{Pre-estimation test}

\subsubsection{Correlation result}

The correlation matrix as presented below helped us to account for the degree of multi-collinearity amidst the variables of the study. According to Gujarati (2003), when the correlation coefficient is greater eight $(>8)$, multicollinearity is suspected in the model. However, multicollinearity is a 
Table 1: Correlation matrix

\begin{tabular}{|c|c|c|c|c|c|c|c|c|c|c|c|c|}
\hline & TFP & AGL & AGLAB & AGMTM & ALOAN & EXR & FALAB & \multicolumn{3}{|c|}{ GROSPRI GROSSEC GROSTER } & LEX & REXPEN \\
\hline TFP & 1 & & & & & & & & & & & \\
\hline AGL & 0.00756 & 1 & & & & & & & & & & \\
\hline AGLAB & 0.01079 & 0.82093 & 1 & & & & & & & & & \\
\hline AGMTM & 0.02399 & 0.85548 & 0.85404 & 1 & & & & & & & & \\
\hline ALOAN & 0.35169 & 0.45593 & 0.20467 & 0.54654 & 1 & & & & & & & \\
\hline EXR & 0.26306 & 0.71815 & 0.52671 & 0.82877 & 0.81633 & 1 & & & & & & \\
\hline FALAB & 0.45992 & 0.56901 & 0.32906 & 0.67678 & 0.83047 & 0.80414 & 1 & & & & & \\
\hline GROSPRI & -0.11582 & -0.54493 & -0.33416 & -0.43589 & -0.35045 & -0.24148 & -0.33424 & 1 & & & & \\
\hline GROSSEC & 0.42954 & 0.57344 & 0.32135 & 0.64013 & 0.74230 & 0.80410 & 0.86876 & -0.32449 & 1 & & & \\
\hline GROSTER & 0.39845 & 0.71155 & 0.50653 & 0.78786 & 0.67097 & 0.88586 & 0.84592 & -0.27726 & 0.83167 & 1 & & \\
\hline LEX & 0.44550 & 0.54105 & 0.25755 & 0.64055 & 0.82157 & 0.81524 & 0.88809 & -0.33341 & 0.80514 & 0.84434 & 1 & \\
\hline REXPEN & 0.26560 & 0.56961 & 0.31616 & 0.62805 & 0.68269 & 0.75388 & 0.76675 & -0.31449 & 0.65200 & 0.74204 & 0.77677 & 1 \\
\hline
\end{tabular}

Source: Authors' own computations 
problem when we have perfect multicollinearity and this is when $I f \mathrm{R}_{\mathrm{k}}{ }_{\mathrm{k}}$ is greater than 0.9 , or the correlation coefficient between the variables is greater nine (>9) (Gujarati, 2003). Hence for this study, there is absence of perfect multi-collinearity among the variables as the pair-wise correlation values are less than 0.9 for the variables. It is also important to note that one of the remedies to multicollinearity according to Gujarati (2003) is to do nothing particularly when there is no redundant variable in the model.

\subsubsection{Unit root test}

The stationarity state of the dataset was ascertained and result shown below.

Table 2: Abridged presentation of unit-root tests using ADF

\begin{tabular}{lccccccc}
\hline Variable & Levels & $\begin{array}{c}\mathbf{5 \%} \\
\text { critical }\end{array}$ & 1st diff & $\mathbf{5 \%}$ critical & 2nd diff & $\begin{array}{c}\mathbf{5 \%} \\
\text { critical }\end{array}$ & Remarks \\
\hline La & -3.6973 & -2.9484 & & & & \\
L & 1.9693 & -2.9484 & -5.3024 & 2.9511 & & & $\mathrm{I}(0)^{*}$ \\
K & -2.9493 & -2.9484 & & & & $\mathrm{I}(0)^{*}$ \\
TFP & -3.2035 & -2.9484 & & & & $\mathrm{I}(0)^{*}$ \\
Alaon & -2.7421 & -2.9484 & -5.1774 & 2.9511 & & $\mathrm{I}(1)^{*}$ \\
Exr & 1.3111 & -2.9484 & -3.66928 & 2.9511 & & $\mathrm{I}(1)^{*}$ \\
Falab & 1.8138 & -2.9484 & -3.41766 & 2.9511 & & $\mathrm{I}(1)^{*}$ \\
Grospri & -1.9160 & -2.9484 & -5.23577 & 2.9511 & & $\mathrm{I}(1)^{*}$ \\
Grossec & -1.8420 & -2.9484 & -6.38576 & 2.9511 & & $\mathrm{I}(1)^{*}$ \\
Groster & -1.3194 & -2.9484 & -6.06587 & 2.9511 & & $\mathrm{I}(1)^{*}$ \\
Lex & 0.7869 & -2.9511 & -1.35522 & 2.9511 & -7.4211 & -2.9540 & $\mathrm{I}(2)^{*}$ \\
Rexpen & -2.7706 & -2.9484 & -6.98918 & -2.9540 & & & $\mathrm{I}(1)^{*}$ \\
R & -4.6147 & -2.9484 & & & & $\mathrm{I}(0)^{*}$ \\
\hline
\end{tabular}

Source: Authors' own computations; *Indicates significant at 5\% level of significance

The above result of the unit root showed different orders of integration. Most variable were integrated of order one. TFP, R, La and $\mathrm{K}$ were stationary at levels while LEX was stationary at first difference. Given that the variables are not all stationary at levels, the existence of long run relationship is suspected. However, with different orders of integration, presence of long run cannot be verified using the Johansen's technique of cointegration. Rather, we employed the ARDL bond testing to ascertain the presence of long-run connectivity among the variables of interest.

\subsection{Presentation and interpretation of ARDL Estimation}

Given the result of the unit root with different orders of integration for the variables, the test of the existence of cointegration cannot be carried out using the Johansen's technique of cointegration. Also the long-run analysis cannot be carried out using the OLS method of estimation to avoid spurious result. Rather we employ the ARDL bond testing and the ARDL regression used in securitizing the factors that will count for enhancing agricultural productivity towards transforming Nigerian rural areas. The outcome is as presented in Table 3 below.

\subsubsection{Establishment of the short-run dynamics}

Given the unit root result where the variables were of different orders and majority of the variables were not stationary at levels, it became necessary to explore the possibility of a long-run and shortrun dynamics among the variables. The study employed the bounds testing (or autoregressive distributed lag (ARDL) cointegration procedure because of its applicability irrespective of whether the regressors in the model are purely $\mathrm{I}(0)$, purely $\mathrm{I}(1)$ or mutually cointegrated as this case. In its basic form, an ARDL regression model is specify thus: 


$$
\Delta y_{t}=\alpha_{0}+\beta_{i} y_{t-1}+\lambda_{k} \sum_{k=1}^{k} \Delta S R_{k, t-1}+\sigma_{k} \sum_{k=1}^{k} L R_{k, t-1}+\mu_{t}
$$

Where: $\Delta$ denotes first difference of variable, $\mu_{t}$ is a random "disturbance" term, $y_{i}$ is the dependent variable (TFP), while $S R$ is the short-run dynamics of explanatory variables, $L R$ is the long-run dynamics of the explanatory variables. $\beta, \lambda$ and $\sigma$ are the parameters to be estimated; $\alpha_{0}$ is the constant parameter. The result as presented in appendix 2 showed absence of long-run dynamics among the variables given the F-sat of 2.000121 which is less than the $5 \%$ level of significance of 2.22 .

\subsubsection{Establishment of ARDL}

Table 3: ARDL Long run estimation

\begin{tabular}{|c|c|c|c|c|}
\hline \multicolumn{5}{|c|}{$\begin{array}{l}\text { Dep. Var = Total factor productivity }(\text { TFP }) \\
\text { Long-run estimation } \\
\text { Method = OLS; } \\
\mathbf{R}^{2}=0.57 \text {; F-Stat. }=3.64 \text { F-Pro. }=0.005 ; \text { DW }=1.61\end{array}$} \\
\hline $\begin{array}{l}\text { Independent } \\
\text { Variable }\end{array}$ & Coefficient & Standard error & t-sat & Probability \\
\hline TFP(-1) & -0.2080 & 0.2728 & -0.7626 & 0.4528 \\
\hline GROSPRIM & -0.0098 & 0.0064 & -1.5310 & 0.1383 \\
\hline GROSSEC & 0.0163 & 0.0167 & 0.9745 & 0.3392 \\
\hline GROSTER & 0.0708 & 0.0416 & 1.7023 & 0.1011 \\
\hline LOG(REXPEN) & -0.0376 & 0.0560 & -0.6705 & 0.5087 \\
\hline EXR & -0.0001 & 0.0019 & -0.0778 & 0.9386 \\
\hline LOG(ALOAN) & -0.1520 & 0.1085 & -1.4005 & 0.1737 \\
\hline FALAB & 0.3473 & 0.1335 & 2.6016 & $0.0154 *$ \\
\hline LEX & -0.2787 & 0.1356 & -2.0547 & $0.0505^{*}$ \\
\hline $\mathrm{C}$ & 1.4024 & 2.7881 & 0.5030 & 0.6194 \\
\hline
\end{tabular}

Source: Authors' own computations; *Indicates significant at $5 \%$ level

The ARDL result demonstrated that the previous levels of productivity negatively impacts on the current level of productivity with no substantial impact. This portrays that the drive towards achieving productivity can effectively be done with effective short run policies. Outcome of the result also showed that the quality of agricultural labour force captured by the educational achievement was positive only at the secondary and tertiary educational level. Primary educational level was negatively related with productivity. The result showed that $1 \%$ change in secondary and tertiary educational level leads to about $2 \%$ and $1 \%$ increase of TFP respectively while $1 \%$ change in primary level of education leads to about $1 \%$ fall in TFP. The above outcome concerning the effect of education on productivity represents the actual need for effective rural transformation. Apart from the NPE and UBE educational policy that are for primary education and are extended to the rural areas, policy on higher educational levels have not been put in place. The recent need for technological advancement in the agricultural activities calls for the need of enhancement of higher educational levels in the rural areas for effective transformation.

As shown by data, in 2013, the gross attendance rate in post-secondary was $2.87 \%$ in rural area and $12.69 \%$ in urban. In same vain, while net attendance rate in primary school was $52.62 \%$ and $76.1 \%$ for rural and urban respectively, in secondary it was $37.37 \%$ and $66.63 \%$ for rural and urban respectively. Proportion of drop out from primary school is also higher in the rural area standing as $42.41 \%$ and $12.71 \%$ for rural and urban respectively (Trading Economics, 2018). Given the dominance of agricultural activity in the rural area, the low quality will doubtlessly hinder the 
productivity of agriculture. The above result on the role of educational levels towards enhancing well-being is harmonious with the findings of Umoru and Ogbeide-Osaretin (2018) on educational attainment for poverty reduction and Kiplimo et al. (2014) on the study of smallholder farmers in Kenya.

Government recurrent expenditure, agric loan and life expectancy rate were negatively related with productivity contrary to expectation while exchange rate and female labour were correctly signed. $1 \%$ increase in rexpen, aloan, exr and lex reduces productivity by $3 \%, 15 \%, 0.01 \%$ and $27 \%$ respectively other factors held constant. On the other hand, $1 \%$ increase in falab increases productivity by $34 \%$. Variables that significantly impact on productivity were female labour force and life expectancy rate at 5\% level of significance. The negative and insignificant impact of finance both from government and loan clearly shows the financial constrain that the agricultural sector in Nigeria is faced with.

Studies are also in support of the insufficient credit that has inhibited agricultural sector's productivity (Akpan et al., 2011); Kiplimo et al (2014) among others. The result of the significant function of female gender in increasing agricultural productivity is coherent with the findings of Adepoju and Salman (2013). Consequently, the impoverishing health condition of rural dwellers has also been shown by the above result. A scenario where the primary health care centers which is the only health care means lacks adequate nurses, no doctors neither are there health equipment and infrastructures. This is also confirmed by Chukwu (2014), that the poor state of health of the rural areas has been a major inhibitor of agricultural productivity.

The fitness of these results was confirmed by the value of multiple determinant of variation $\mathrm{R}^{2}$ the F-statistics and DW-statistics as shown in Table 3. The regressors in the model explained $56 \%$ of the variation in total factor productivity which is not a bad fit. The F-statistics and DW-statistics confirmed the facts that the overall model exhibits good fit and no problems of autocorrelation in the model.

\section{POLICY IMPLICATION OF EMPIRICAL FINDINGS}

\subsection{Policy implications}

Based on our empirical estimates, the study has shown that enhancing agricultural productivity towards perking up the quality of life in the rural areas rests on some specific areas to be considered. The following policy implications are drawn from the result.

i. Educational levels used to measure the quality of labour showed that only secondary and tertiary levels of education can increase agricultural productivity. This is highly shown by the high percentage of unemployment at the primary level in Nigeria. So, policies of increasing productivity towards transforming the rural areas demands - investments beyond the primary level of education to higher educational levels. Educational infrastructure facilities to enhance the teaching and learning in the rural areas are urgently needed in line with the rural transformation agenda as presented in the IFAD (2016).

ii. The negative and insignificant impact of government expenditure and loan showed that dearth of credit is a major obstacle to the productivity of the agricultural sector. If there is going to be rural transformation in Nigeria, it is important that the increase of credit availability be a priority for both government, commercial banks and private individuals. Although over time government has made an effort in providing credit to farmers, most often, the farmers claims not to have access to these credit facilities. Hence, feedback and accountability part of policy formulation should be enforced.

iii. The result of the empirical estimate showed clearly the significance of female labour force in the productivity of agriculture in Nigeria with the variable having the highest coefficient. Given this, rural transformation policies in Nigeria should provide explicit room to enhance the 
productivity of the female gender through increasing their access to education, health, credit and land.

iv. Health which is needed for human capital development was negatively related to productivity which is contrary to expectation showing that the poor health status of the rural people has been a major constraint to the productivity of the agricultural sector in Nigeria. However, it finds significant. The health status of the rural people is of immense need for effective transformation. It is thus recommended that the provision of health facilities should be accelerated in the rural areas so that the health status of the people can be improved.

v. In addition to the above findings, the insignificant negative effect of exchange shows that our agricultural export is not competitive in the foreign market. However, agricultural export can be a major avenue of diversifying Nigerian economy. Hence, exports can be made competitive by increasing innovation and technology of production for productivity as has also been recommended (Muzari et al., 2012; Iheke and Nwaru, 2013). Policy formulation on the increase in government expenditure on agricultural technology will generate higher growth in agricultural productivity and higher quality of output.

\subsection{Conclusion}

For sustainable development, rural transformation and development cannot be neglected. In the drive for the advancement of the well-being of the rural dwellers, the preferment of agricultural productivity is inevitable given that agriculture is the major occupation of the rural areas. Results of this study have shown that there is need for promotion of investment in health, education (particularly beyond primary level) and technology in the rural areas. The results of this study are consistent with other studies. The study also concludes that the position of female gender is imperative and should be given a priority in the formulation of policies for the provision of access to credit, health, education and technologies.

Funding: This study received no specific financial support.
Competing Interests: The authors declared that they have no conflict of interests.
Contributors/Acknowledgement: All authors participated equally in designing and estimation of current
research.
Views and opinions expressed in this study are the views and opinions of the authors, Asian Journal of
Agriculture and Rural Development shall not be responsible or answerable for any loss, damage or liability
etc. caused in relation to/arising out of the use of the content.

\section{References}

Adepoju, A. A., \& Salman, K. K. (2013). Increasing agricultural productivity through rural infrastructure: evidence from Oyo and Osun States, Nigeria. International Journal of Applied Agricultural and Apicultural Research, 9(172), 1-10.

AGRA (Alliance for a Green Revolution in Africa) (2017). Africa agriculture status report: the business of smallholder agriculture in Sub-Saharan Africa (Issue 5). Nairobi, Kenya. Retrieved from https://agra.org/wp-content/uploads/2017/09/Final-AASR-2017-Aug28.pdf.

Akpan, S. B., Aya, E. A., Essien, U. A., Akpan, O. D., \& Bassey, N. E. (2011). Analysis of total factor productivity among smallholder vegetable farmers in Akwa-Ibom State, Nigeria, Journal of Agriculture, Food and Environment, 7(4), 68-74.

Alilu, A., \& Ichoku, H. E. (2015). Total factor productivity dynamics in Sub-Saharan Africa: Malmquist Index Approach. International Business and Management, 10(3), 54-73. DOI: http://dx.doi.org/10.3968/6868.

Asoegwu, S. N., \& Asoegwu, A. O. (2007). An overview of agricultural mechanism and its environmental management in Nigeria. Agricultural Engineering International: The CIGR Ejournal, 6(9), 1-22. 
ASTI (2018). Agricultural science and technology indicators: Nigeria. Retrieved from https://www.asti.cgiar.org/nigeria.

Barrett, C. B., Christiaensen, L., Sheahan. M., \& Shimeles. A. (2017). On the structural transformation of Rural Africa. Policy Research Working Paper 7938, January. Retrieved from http://documents.worldbank.org/curated/en/527271484057904631/pdf/WPS7938.pdf.

Beegle, K., Christiaensen, L., Dabalen, A., \& Gaddis, I. (2016). Poverty in a Rising Africa. World Bank. Washington, DC. USA. Retrieved from https://openknowledge.worldbank.org/handle/10986/22575

Benjamin, C. A., \& Victoria A. O. (2012). Marketing of agricultural produce among rural farm households in Nigeria: The case of sorghum marketing in Benue State. International Journal of Business and Social Science, 3(13), 269 -270.

Brady, M., \& Sohngen, B. (2008). Agricultural productivity, technological change, and deforestation: a global analysis. Selected Paper prepared for presentation at the American Agricultural Economics Association Annual Meeting, Orlando, FL, July 27-29.

Bustos, P., Caprettini, B., \& Ponticelli, J. (2016). Agricultural productivity and structural transformation. Evidence from Brazil. American Economic Review, 106(6), 1320-1365. http://dx.doi.org/10.1257/aer.20131061

CBN - Central Bank of Nigeria - (2017). Statistical bulletin. Abuja: CBN Publications, Nigeria.

Chukwu, E. O. (2014). Agricultural crop-sector productivity analysis in Nigeria between 1970 and 2013. Nigeria Journal of Agriculture, Food and Environment, 10(2), 91-96.

Coelli, T. J., \& Rao, P. D. S. (2003). Total factor productivity growth in agriculture: a Malmquist index analysis of 93 countries, 1980-2000. Presented at International Association of Agricultural Economics (IAAE) Conference in Durban, August 16-22.

Dabla-Norris, E., Thomas, A., Garcia-Verdu, R., \& Chen, Y. (2013). Benchmarking structural transformation across the World, International Monetary Fund WP 13/176. https://www.imf.org/en/Publications/WP/Issues/2016/12/31/Benchmarking-StructuralTransformation-Across-the-World-40847.

Eboh, E., Oduh, M., \& Ujah, O. (2012). Drivers and sustainability of agricultural growth in Nigeria. African Institute for Applied Economics (AIAE) Research Paper 8. www.aiaenigeria.org.

Eze, S. O., Onwubuya, E. A., \& Ezeh, A. N. (2010). Women marketers' perceived constraints on selected agricultural produce marketing in Enugu south area: challenges of extension training for women groups in Enugu state, Nigeria. Agro-Science, 9(3), 215-222.

FAO (Food and Agriculture Organization) (2012). Smallholders and family farmers. Sustainability Pathways Fact Sheet. Rome: Food and Agriculture Organization of the United Nations. Available

www.fao.org/fileadmin/templates/nr/sustainability_pathways/docs/Factsheet_SMALLHOL DERS.pdf.

Grosskopf, S. (1993). Efficiency and productivity. in Fried HO and SS Schmidt (eds.) the measurement of productive efficiency: techniques and applications, Oxford U.K.: 160-194. http://deazone.com/en/grosskopf-s-1993-efficiency-and-productivity-in-fried-ho-and-ssschmidt-eds-the-measurement-of-productive-efficiency-techniques-and-applicationsoxford-u-k-160-194.

Gujarati, D. N. (2003). Basic econometrics. (4 ${ }^{\text {th }}$ edition) New York: McGraw Hill Inc. hareng.com/admin/upload/reports/10910-oshareConfidentialDecember2017- proshare.pdf.

Hayami, Y. (2001). Development Economics: From Poverty Alleviation to the Wealth of Nations. $2^{\text {nd }}$ Edition. New York: Oxford University Press.

Hayami, Y., \& Ruttan, V. W. (1985). Agricultural development: an international perspective (revised and expanded). Baltimore MD, and London: Johns Hopkins University Press.

IAASTD (2009). Agriculture at a crossroads. International Assessment of Agricultural Knowledge, Science and Technology for Development, Sub-Saharan Africa (SSA) Report. http://www.fao.org/fileadmin/templates/est/Investment/Agriculture_at_a_Crossroads_Glob al_Report_IAASTD.pdf. 
Ibok, O. W., Idiong, I. C., Bassey, N. E., \& Udoh, E. S. (2014). Food security and productivity of urban food crop farming households in Southern Nigeria. Agricultural Science, 2(3), 1-12.

IFAD (International Fund for Agricultural Development) (2016). Rural Development Report 2016: fostering inclusive rural transformation. Rome, Italy: International Fund for Agricultural Development

(IFAD). https://www.ifad.org/documents/30600024/30604583/RDR WEB.pdf/c734d0c4-fbb1$4507-9 \mathrm{~b} 4 \mathrm{~b}-6 \mathrm{c} 432 \mathrm{c} 6 \mathrm{f} 38 \mathrm{c} 3$.

Iheke, O. R., \& Nwaru, J. C. (2013). Innovation adoption, farm productivity and poverty status of rural smallholder farm households in South-East, Nigeria. Paper presented at the $4^{\text {th }}$ International Conference of the African Association of Agricultural Economists, September 22-25, 2013. Hammamet, Tunisia. http://ageconsearch.umn.edu/bitstream/161627/2/Onwuchekwa\%20Raphael\%20Iheke\%20a nd\%20Jude\%20Chukwudi\%20Nwaru.pdf.

Johnston, B. F., \& Mellor, J. W. (1961). The role of agriculture in economic development. American Economic Review, 51(4), 566-593.

Kanu, S. B., Salami, O. A., \& Numasawa (2014). Inclusive growth: An imperative for African agriculture. Africa Development Bank, www.afdb.org/fileadmin/uploads/afdb/Documents/Publications/Inclusive_Growth_An imperative_for_African_Agriculture.pdf.

Kiplimo, J. C., Ngenoh, E., Koech, W., \& Bett, J. K. (2014). Determinants of access to credit financial services by smallholder farmers in Kenya. Journal of Development and Agricultural Economics, 7(9), 303-313.

Mankiw, N. G. (2002). Macroeconomics. Fifth edition. New York, Wort Publishers.

Mbabazi, J., Bah, M. E., \& Verdier-Chouchane, A. (2015). Transforming Africa's agriculture to improve competitiveness. Retrieved from Africa Competitiveness: http://reports.weforum.org/africa-competitiveness-report-2015/chapter-2-1-transformingafricas-agriculture-to-improve-competitiveness/.

Mensah, O. S., Jincai, Z., Isaac, A. B., \& Patrick, A. (2017). The role of institutional policies in promoting agribusiness development in Rural China. Agriculture and Food Sciences Research, 4(2), 37-44.

Miles, D., \& Scott, A. (2005). Macroeconomics: Understanding the global economy. Second Edition, Wiley and Sons.

Muzari, W., Gatsi, W., \& Muvhunzi, S. (2012). The impacts of technology adoption on smallholder agricultural productivity in Sub-Saharan Africa: A Review. Journal of Sustainable Development, 5(8), 69-77.

NBS (2018). Labour force statistics. Vol. 2: Employment by Sector Report, January 2018 (Q3 2017).

Nin, A., Arndt, C., Hertel, W., \& Preckel, P. V. (2003). Bridging the gap between partial and total factor productivity measures using directional distance functions. American Journal of Agricultural Economics, 85(4), 928-942. November, https://doi.org/10.1111/1467$\underline{8276.00498}$.

Nwangi, M., \& Kariuki, S. (2015). Factors determining adoption of new agricultural technology by smallholder farmers in developing countries. Journal of Sustainable Development, 6(5), 208-216.

Odhiambo, W., \& Nyangito, H. O. (2003). Measuring and analysing agricultural productivity in Kenya: a review of approaches. Productive Sector Division Kenya Institute for Public Policy Research and Analysis KIPPRA Discussion Paper No. 26, January.

OECD Organisation for Economic Co-operation and Development (2001). Measuring productivity: measurement of aggregate and industry-level productivity growth. Sources from http://www.oecd.org/sdd/productivity-stats/2352458.pdf.

Olagunju, F. I. (2010). Impact of credit on poultry productivity in Southwestern Nigeria. World Rural Observations, 2(4), 59-65. 
Onyeabor, E. N. (2009). Marketing and distribution channels; agricultural marketing for developing economics. Enugu Jacob's Classic Publishers Ltd; 4-25.

Partnership for African Development, (NEPAD) (2013). Agriculture in Africa, transformation and outlook. Retrieved from http://www.un.org/en/africa/osaa/pdf/pubs/2013africanagricultures.pdf.

TheGlobaleconomy.com. (2019). Food production index-country ranking. Retrieved from https://www.theglobaleconomy.com/rankings/food_production_index/.

Trading Economics (2018). Nigeria-Gross enrolment ratio, primary and secondary, female. Retrieved from https://radingeconomics.com/nigeria/gross-enrolment-ratio-primary-andsecondary-female-percent-wb-data.html.

Umoru, D., \& Ogbeide-Osaretin, N. E. (2018). Econometric analysis of unemployment and poverty in Nigeria: the role of education. Journal of Academic Research in Economics, 10(1), 94110.

UNCTD (United Nations Conference on Trade and Development) (2016). Total labour force and agriculture labour force. annual, 1980-2020, September, available at http://unctadstat.unctad.org/TableViewer/tableView.aspx?ReportId=94.

World Bank (2017). World development indicators. Statistical database. World Bank, Washington DC, USA.

World Bank (2017). The 2017 global poverty update from the World Bank. Retrieved from http://blogs.worldbank.org/developmenttalk/2017-global-poverty-update

Zepeda, L. (2001). Agricultural investment. Production capacity and productivity, in FAO Economic and Social Development Paper 148. Food and Agriculture Organization of the United Nations. http://www.fao.org/docrep/pdf/003/x9447e/x9447e.pdf. 


\section{Appendix}

Appendix 1: ARDL long run estimation

Dependent Variable: TFP

Method: ARDL

Date: 12/02/19 Time: 11:20

Sample (adjusted): 19822016

Included observations: 35 after adjustments

Maximum dependent lags: 1 (Automatic selection)

Model selection method: Akaike info criterion (AIC)

Dynamic regressors (0 lag, automatic): GROSPRIM GROSSEC GROSTER

LOG(REXPEN) EXR LOG(ALOAN) FALAB LEX

Fixed regressors: $\mathrm{C}$

\begin{tabular}{lcccc} 
Variable & Coefficient & Std. Error & t-Statistic & Prob.* \\
TFP(-1) & -0.2081 & 0.2728 & -0.7626 & 0.4528 \\
GROSPRIM & -0.0098 & 0.0064 & -1.5310 & 0.1383 \\
GROSSEC & 0.0163 & 0.0167 & 0.9745 & 0.3392 \\
GROSTER & 0.0708 & 0.0416 & 1.7023 & 0.1011 \\
LOG(REXPEN) & -0.0376 & 0.0560 & -0.6705 & 0.5087 \\
EXR & -0.0001 & 0.0019 & -0.0778 & 0.9386 \\
LOG(ALOAN) & -0.1520 & 0.1085 & -1.4005 & 0.1737 \\
FALAB & 0.3473 & 0.1335 & 2.6016 & $0.0154^{*}$ \\
LEX & -0.2787 & 0.1356 & -2.0547 & $0.0505^{*}$ \\
C & 1.4024 & 2.7881 & 0.5030 & 0.6194 \\
R-squared & 0.5672 & Mean dependent var & -0.0075 \\
Adjusted R-squared & 0.4114 & S.D. dependent var & 0.2463 \\
S.E. of regression & 0.1889 & Akaike info criterion & -0.2600 \\
Sum squared resid & 0.8923 & Schwarz criterion & 0.1844 \\
Log likelihood & 14.5492 & Hannan-Quinn criter. & -0.1066 \\
F-statistic & 3.6406 & Durbin-Watson stat & 1.6100 \\
Prob(F-statistic) & 0.0050 & & \\
*Note: p-values and any subsequent tests do not account for model section & \\
\hline
\end{tabular}

Source: Authors' own computations; *Indicates significant at $5 \%$ level of significance

Appendix 2: ARDL bound testing for cointegration

ARDL Bounds Test

Date: 10/17/18 Time: 11:17

Sample: 19822016

Included observations: 35

Null Hypothesis: No long-run relationships exist

$\begin{array}{lcc}\text { Test Statistic } & \text { Value } & \text { K } \\ \text { F-statistic } & 2.000121 & 8 \\ \text { Critical Value Bounds } & & \\ \text { Significance } & \text { I0 Bound } & \text { I1 Bound } \\ 10 \% & 1.95 & 3.06 \\ 5 \% & 2.22 & 3.39 \\ 2.5 \% & 2.48 & 3.7 \\ 1 \% & 2.79 & 4.1 \\ \text { Test Equation: } & \\ \text { Dependent Variable: D(TFP) } & \end{array}$


Method: Least Squares

Date: 10/17/18 Time: 11:17

Sample: 19822016

Included observations: 35

\begin{tabular}{|c|c|c|c|c|}
\hline Variable & Coefficient & Std. Error & t-Statistic & Prob. \\
\hline D(GROSPRIM) & -0.0134 & 0.0114 & -1.1820 & 0.2511 \\
\hline D(GROSSEC) & 0.0306 & 0.0228 & 1.3416 & 0.1948 \\
\hline D(GROSTER) & 0.1092 & 0.0511 & 2.1365 & $0.0452 *$ \\
\hline $\mathrm{D}(\mathrm{EXR})$ & -0.0046 & 0.0026 & -1.7854 & 0.0894 \\
\hline DLOG(ALOAN) & 0.1595 & 0.1818 & 0.8770 & 0.3909 \\
\hline $\mathrm{C}$ & -0.9726 & 4.1200 & -0.2361 & 0.8158 \\
\hline GROSPRIM(-1) & -0.0133 & 0.0098 & -1.3583 & 0.1895 \\
\hline GROSSEC(-1) & 0.0152 & 0.0301 & 0.5045 & 0.6195 \\
\hline GROSTER(-1) & 0.0334 & 0.0586 & 0.5704 & 0.5748 \\
\hline LOG(REXPEN(-1)) & 0.0086 & 0.0779 & 0.1099 & 0.9136 \\
\hline $\operatorname{EXR}(-1)$ & 0.0016 & 0.0026 & 0.6074 & 0.5504 \\
\hline LOG(ALOAN(-1)) & -0.1871 & 0.1582 & -1.1825 & 0.2509 \\
\hline $\operatorname{FALAB}(-1)$ & 0.1256 & 0.2054 & 0.6118 & 0.5476 \\
\hline $\operatorname{LEX}(-1)$ & -0.0529 & 0.2201 & -0.2402 & 0.8126 \\
\hline $\operatorname{TFP}(-1)$ & -1.2509 & 0.3531 & -3.5430 & $0.0020 *$ \\
\hline R-squared & 0.5835 & \multicolumn{2}{|c|}{ Mean dependent var } & -0.0160 \\
\hline Adjusted R-squared & 0.2920 & \multicolumn{2}{|c|}{ S.D. dependent var } & 0.2413 \\
\hline S.E. of regression & 0.2030 & \multicolumn{2}{|c|}{ Akaike info criterion } & -0.0537 \\
\hline Sum squared resid & 0.8242 & \multicolumn{2}{|c|}{ Schwarz criterion } & 0.6129 \\
\hline Log likelihood & 15.9398 & \multicolumn{2}{|c|}{ Hannan-Quinn criter. } & 0.1764 \\
\hline F-statistic & 2.0015 & \multicolumn{2}{|c|}{ Durbin-Watson stat } & 2.2264 \\
\hline Prob(F-statistic) & 0.0762 & & & \\
\hline
\end{tabular}

Source: Authors' own computations; *Indicates significant at $5 \%$ level of significance

TFP

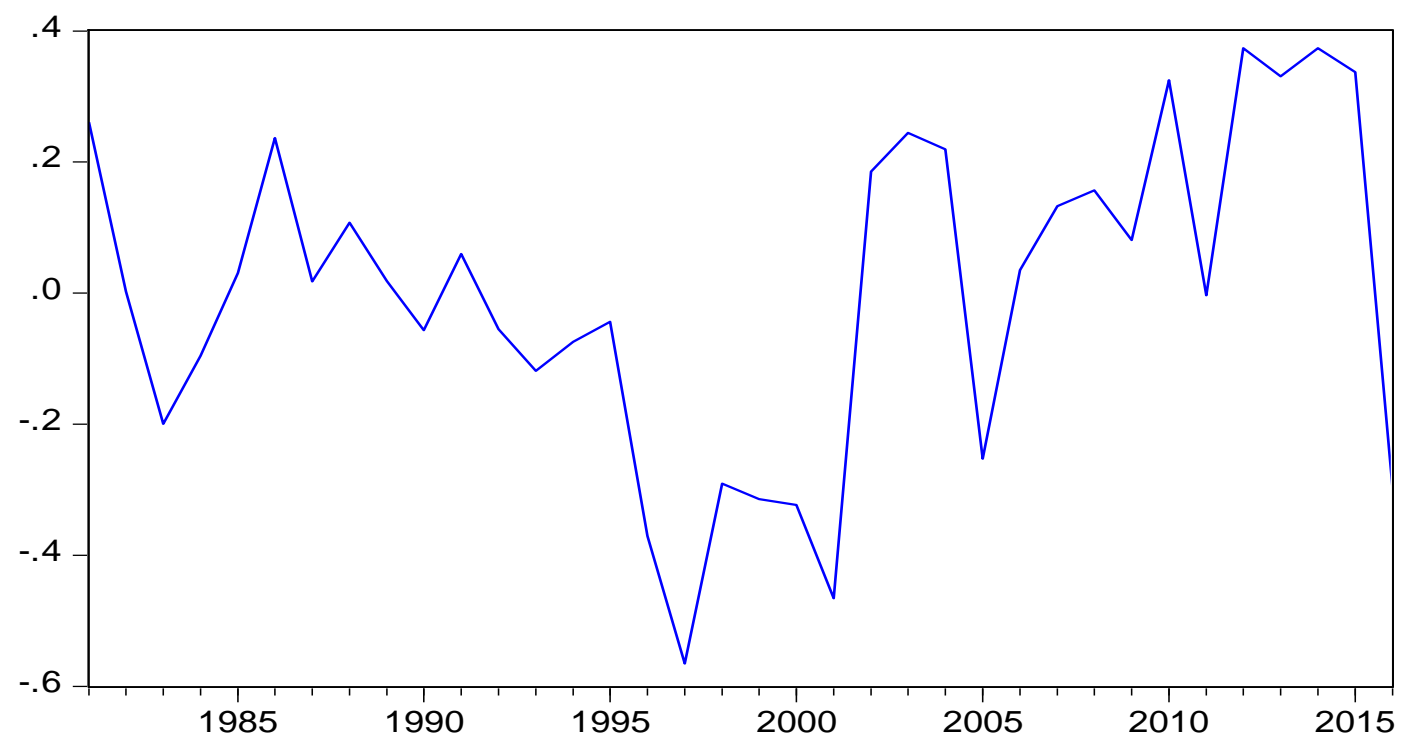

